\title{
PEMILIHAN KARIR SEBAGAI AKUNTAN PUBLIK BAGI MAHASISWA PERGURUAN TINGGI SWASTA DENGAN PENDEKATAN THEORY OF PLANNED BEHAVIOUR
}

\author{
Hendro Lukman \& Sugim Winata \\ Universitas Tarumanagara \\ Email: hendrolukman@gmail.com
}

\begin{abstract}
The purpose of this study is to see how the attitude, subject norms, perceived behavior control and intention to behavior for a career as a public accountant in the perception of accounting students at private universities in Jakarta by using the approach of The Theory of Planned Behaviour (TPB). Data collected for processed were total of 106 questionnaires. Data processed by using Stata, showed that attitude, subject norms and perceived behavior control has a weak correlation and no significant effect among those variables, on student intention became public accountants, and to the behavior of a career as a public accountant through intention as mediating variable. However, the relationship between intention on student become a public accountant to the behavior of a career as a public accountant has a strong relationship and have a significant impact. It can be concluded that the respondents' interest in working as a public accountant only temporarily as a stepping stone to other professions,
\end{abstract}

Keywords: Public Accountnt Career, TPB approach

\begin{abstract}
Abstrak: Tujuan dari penelitian ini adalah untuk melihat bagaimana sikap, norma subjek, persepsi perilaku dan perilaku yang dirasakan terhadap perilaku berkarir sebagai akuntan publik dalam persepsi mahasiswa akuntansi di perguruan tinggi swasta di Jakarta dengan menggunakan pendekatan Teori Perilaku Terencana (TPB). Data yang dikumpulkan untuk diproses adalah sebanyak 106 kuesioner. Data yang diolah dengan menggunakan Stata, menunjukkan bahwa sikap, norma subjek dan persepsi kontrol perilaku memiliki korelasi yang lemah dan tidak berpengaruh signifikan diantara variabel tersebut, pada niat siswa menjadi akuntan publik, dan perilaku karir sebagai akuntan publik melalui niat sebagai mediasi. variabel. Namun, hubungan antara niat pada siswa menjadi akuntan publik terhadap perilaku berkarya sebagai akuntan publik memiliki hubungan yang kuat dan memiliki dampak signifikan. Dapat disimpulkan bahwa minat responden untuk bekerja sebagai akuntan publik hanya sementara sebagai batu loncatan untuk profesi lain,
\end{abstract}

Kata kunci: Public Accountnt Career, pendekatan TPB

\section{PENDAHULUAN}

Masyarakat Ekonomi ASEAN (MEA) telah dimulai pada tahun 2015, merupakan manifestasi kesiapan Association of Southeast Asian Nations (ASEAN) sebagai kawasan perdagangan bebas barang, jasa, investasi, tenaga kerja, dan aliran modal yang lebih bebas yang bersaing secara global dalam ruang lingkup internasional. Dalam mempersiapkan MEA tentunya menuntut berbagai segmen profesi untuk memiliki kemampuan, pengetahuan dan daya saing yang tinggi . Salah satu profesi Akuntan. 
Menurut data Ikatan Akuntansi Indonesia (IAI), Indonesia yang memiliki penduduk 250 juta jiwa memiliki 24.587 akuntan yang terdaftar pada IAI pada tahun 2015 dari 35.000 sarjana akuntansi (sumber : World Bank tahun 2015) yang dihasilkan dari 1.223 institusi perguruan tinggi fakultas ekonomi bisnis (sumber : forlap.dikti.go.id) yang di dalamnya terdapat jurusan akuntansi, dan hanya 1.138 yang berprofesi sebagai akuntan publik pada tahun 2016. Berdasarkan data di atas mengindikasikan bahwa rendahnya jumlah lulusan sarjana akuntansi yang mengambil profesi sebagai akuntan publik di Indonesia yang tidak sebanding dengan jumlah penduduk Indonesia dan tentunya kebutuhan dunia usaha.

Kebutuhan tenaga akuntan publik dalam MEA emang unik dibanding dengan profesi akuntan lainnya, seperti akuntan manajemen, akuntan pendidik dan akuntan non asurans. Akuntan manajemen, akuntan pendidik dan akuntan non asurans dapat dengan mudah melakukan pekerjaan di negara manapun dalam wilayah negara yang bergabung dalam ASEAN. Tidak hal dengan akuntan publik, seorang akuntan publik dalam melakukan tugasnya masih mengikuti pakem negara masing-masing.

Profesi akuntan publik yang merupakan profesi yang independen dalam memberikan opini atas laporan keuangan entias secara handal, transparan dan apa adanya sesuai dengan standar pemeriksaan yang berlaku.

Menurut Zaid (2015) laporan keuangan merupakan hal yang sangat penting untuk mengukur kinerja suatu perusahaan, sehingga pelaporan keuangan yang transparan dan dapat diandalkan merupakan kebutuhan yang mutlak untuk mengakomodir kepentingan para stakeholders perusahaan. Menurut Gray, dkk menyatakan audit sebagai alat untuk membukikan bahwa informasi yang disiapkan oleh organisasi dapat dihandalkan (Gray 2015: 21) dan sebagai suatu opini asurans atas kebenaran dan kewajaran laporan keuangan berdasarkan kualitas dari pernyataan tersebut (Gray 2015: 23).

Rendahnya jumlah akuntan publik yang ada di Indonesia dan minat mahasiswa akuntansi terhadap profesi akuntan publik menjadi perhatian serius , baik dari pemerintah maupun organisasi profesi akuntan publik (Sulistiani,2012). Organisasi profesi akuntan publik dan akademisipun berusaha keras terkait isu mengenai rendahnya daya tarik profesi akuntan publik di kalangan mahasiswa akuntansi sendiri.

Sugahara dan Boland (2006) merekomendasikan dua cara untuk mendorong mahasiswa mengikuti Certified Public Accountant (CPA) exam yaitu mendukung dan membantu mahasiswa yang memang berniat untuk berkarir sebagai akuntan publik serta mendorong mereka untuk tidak mengubah pilihan karirnya tersebut. Kedua, pihak akademisi perlu menginspirasi dan memotivasi mahasiswa yang belum tertarik menjadi akuntan publik (terutama pada mahasiswa akuntansi) mengenai reward dan keutamaan lain bila mereka menjadi akuntan publik. Untuk mewujudkan kedua hal tersebut, perlu diketahui persepsi mahasiswa sendiri mengenai akuntan publik.

Pihak profesi akuntan publik dan akademisi mengembangkan strategi untuk menarik minat mahasiswa akuntansi berkarir sebagai akuntan publik. Persepsi mahasiswa atas suatu profesi memainkan peranan yang penting dalam pemilihan karir mereka (Sugahara dan Boland, 2006). Menurut Andersen (2012) mahasiswa akan dihadapkan pada pilihan untuk memilih karir sebagai akuntan publik., namun tidak semua mahasiswa akuntansi memilih untuk bekerja sebagai akuntan publik. Keputusan timbul saat seseorang menetapkan pilihan atas beberapa alternatif yang tersedia di hadapannya, tetapi konsekuensinya sangat menentukan di masa selanjutnya. Sebagai individu, setiap saat 
manusia melakukan pembuatan keputusan baik untuk kepentingan pribadi maupun untuk orang banyak atau organisasi.

\section{KAJIAN TEORI}

Theory of Planned Behavior (TPB) yang merupakan perbaikan dari permasalahan yang tidak ditujukan padanTheory of Reasoned Action (TRA) (Hasullah, Mahajar, Salleh 2014). Mengembangkan teori ini dengan menambahkan konstruk yang belum ada di TRA. Konstruk ini di sebut dengan kontrol persepsi perilaku (perceived behavioral control). Konstruk ini ditambahkan pada TPB untuk mengendalikan perilaku individual yang dibatasi oleh kekurangan-kekurangannya dan keterbatasan-keterbatasan dari kekurangan sumber-sumber daya yang digunakan untuk melakukan perilakunya (Hsu dan Chiu 2002). Dengan menambahkan sebuah konstruk ini, yaitu kontrol persepsi perilaku (Perceived behavioral control), maka bentuk dari model teori perilaku rencanaan (Theory of planned behavior atau TPB) tampak di gambat berikut ini.

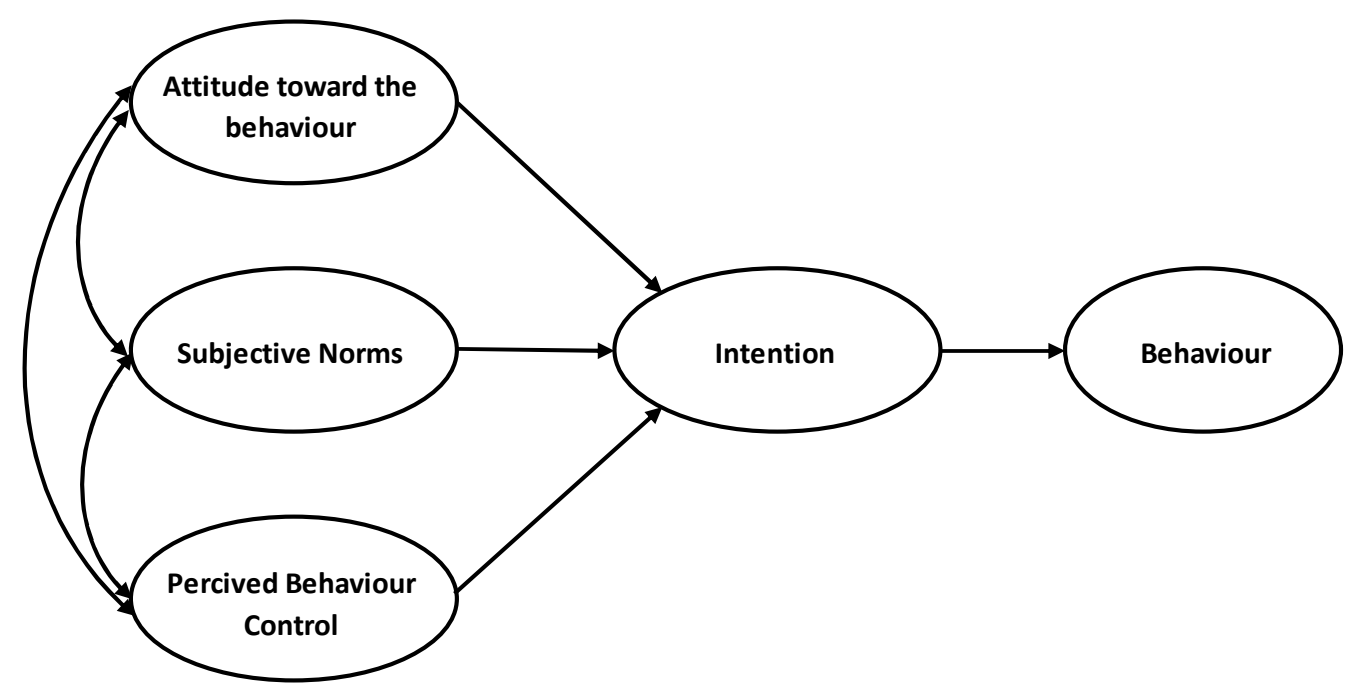

Gambar 1. Theory of Planned Behavioral

Sumber: Ajzen ( 1991)

TPB dua fitur (Jogiyanto, 2007) yaitu:

1. Teori ini mengansumsi bahwa kontrol persepsi perilaku (perceived behavioral control) mempunyai implikasi motivasional terhadap minat. Orang yang percaya bahwa mereka tidak mempunyai sumber- sumber daya yang ada atau tidak mempunyai kesempatan untuk melakukan perilaku tertentu mungkin tidak akan membentuk minat berperilaku yang kuat untuk melakukannya walaupun mereka mempunyai sikap yang positif terhadap perilakunya dan percaya bahwa orang lain akan menyetujui seandainya mereka melakukan perilaku tersebut. Dengan demikian diharapkan terjadi hubungan antara kontrol persepsi perilaku (perceived behavioral control) dengan minat yang tidak dimediasi oleh sikap dan norma subyektif. Di model ini ditunjukkan dengan 
panah yang menghubungkan kontrol persepsi perilaku ( perceived behavioral control) ke minat.

2. Kemungkinan hubungan langsung antara kontrol persepsi perilaku (perceived behavioral control) dengan perilaku. Kinerja dari suatu perilaku tergantung tidak hanya pada motivasi untuk melakukannya tetapi juga kontrol yang cukup terhadap perilaku yang dilakukan. Dengan demikian. Kontrol perilaku persepsian (perceived behavioral control) dapat mempengaruhi perilaku secara tidak langsung melalui minat, dan juga dapat memprediksi perilaku secara langsung. Pada model, hubungan langsung ini ditunjukan dengan panah yang menghubungkan kontrol persepsi perilaku (perceived behavioral control) langsung ke perilaku (behavior).

Kontrol perilaku yang dirasakan dipengaruhi oleh pengalaman masa lalu dan perkiraan seseorang mengenai sulit atau tidaknya untuk melakukan perilaku tertentu (Azwar, 2003). TPB mengganggap bahwa teori sebelumnya mengenai perilaku yang tidak dapat dikendalikan oleh individu melainkan juga dipengaruhi oleh faktor non motivasional yang dianggap sebagai kesempatan atau sumber daya yang dibutuhkan agar perilaku dapat dilakukan. Sehingga dalam teorinya, Ajzen menambahkan satu determinan lagi, yaitu kontrol persepsi perilaku mengenai mudah atau sulitnya perilaku yang dilakukan. Oleh karena itu menurut TPB, intensi dipengaruhi oleh tiga hal yaitu: sikap, norma subjektif, kontrol perilaku (Ajzen 1991).

Dalam theory of planned behavior (TPB), perilaku yang ditampilkan oleh individu timbul karena adanya niat untuk berperilaku (behavioral intention) (Jogiyanto, 2007) :

1. Kepercayaan perilaku (behavioral belief), yaitu kepercayaan tentang kemungkinan terjadinya perilaku. Kepercayaan perilaku akan menghasilkan suatu sikap menyukai atau tidak menyukai terhadap perilaku.

2. Kepercayaan normatif (normative belief), yaitu kepercayaan tentang ekspektasi normatif dari orang lain dan motivasi untuk menyetujui ekspektasi tersebut. Kepercayaan normatif menghasilkan tekanan sosial atau norma subjektif.

3. Kepercayaan kontrol (control belief), yaitu kepercayaan tentang keberadaan faktorfaktor yang akan memfasilitasi atau merintangi kinerja dari perilaku dan kekuatan persepsian dari faktor-faktor tersebut. Kepercayaan kontrol akan menghasilkan kontrol persepsi perilaku.

Lebih lanjut, secara bersamaan, sikap terhadap perilaku (attitude toward behavior), norma-norma subjektif (subjective norms), dan kontrol pesepsi perilaku (perceived behavioral control) akan mengakibatkan niat perilaku (behavioral intention) dan yang selanjutnya akan menimbulkan perilaku (behavior) sehingga diharapkan dengan mengidentifikasi sikap. Dalam hal ini, mahasiswa akuntansi terhadap profesi akuntan publik, norma-norma subjektif, dan kontrol persepsi perilaku akan dapat memprediksi niat mahasiswa akuntansi untuk menjadi akuntan publik dan perilaku pemilihan karir sebagai akuntan publik.

1. Sikap (Attitude). Sikap (attitude) dapat didefiniskan secara secara psikis adalah sebagai cara aksi atau bertindak dalam sesuatu hal. Sikap dapat dilakukan baik secara sadar dan tidak sadar. Sedangkan menurut Ajzen dan Fishbein (1977) mengadakan bahwa sikap menyatakan bahwa sikap dilakukan sehubungan dengan beberapa aspek dunia individu, seperti orang lain, obyek fisik, perilaku, atau kebijakan. Oleh karena itu, cara seseorang bereaksi terhadap lingkungannya disebut sikap. Baron \& Byrne (1984) mendefinisikan sikap sebagai kelompok yang relatif abadi dari perasaan, keyakinan, dan kecenderungan perilaku yang diarahkan ke orang khusus, ide-ide, obyek atau 
kelompok. Sikap sangat diperlukan dalam menghadapi persaingan di dunia kerja saat ini. Individu pada dasarnya telah memiliki pilihan sendiri, dia memilih apa yang dia anggap baik dan disukainya. Pada sisi ini sikap seolah-olah mengarahkan pilihan dan tindakan individu.

2. Norma-norma Subyektif (Subjective Norms). Norma subyektif merujuk persepsi individu dari tekanan sosial untuk melakukan atau tidak melakukan suatu perilaku (Ajzen 1991). Bagley, Dalton, Ortegen (2012) berpendapat bahwa norma subyektif dalam TPB adalah perasaan atau dugaan-dugaan seseorang terhadap harapan-harapan dari orang-orang yang ada di sekitarnya. Selain itu apa yang ada dalam lingkungan sosial akan menimbulkan suatu norma subyektif. Misalnya mahasiswa akuntansi memilih bekerja sebagai akuntan publik karena melihat saudara yang sukses bekerja sebagai akuntan publik, serta banyak kerabat dan temannya yang beranggapan bahwa profesi akuntan publik adalah profesi yang prestise. Pengaruh tersebut dapat berasal dari orang tua, keluarga, teman atau rekan kerja, dosen di universitas dan pakar profesional dari suatu profesi.

3. Kontrol Persepsi Prilaku (perceived behavior control). Kontrol Persepsi Prilaku mengacu pada keyakinan individu mengenai tingkat kesulitan yang dibutuhkan untuk melakukan perilaku yang menjadi perhatian (Ajzen 1991). Persepsi ini dapat berasal dari pengalaman masa lalu dan juga mengantisipasi halangan-halangan yang ada (Jogiyanto, 2007: 65). Kontrol persepsi perilaku merupakan kondisi di mana orang percaya bahwa suatu tindakan itu mudah atau sulit dilakukan, mencakup juga pengalaman masa lalu di samping rintangan-rintangan yang ada yang dipertimbangkan oleh orang tersebut

Dalam TPB yang dikembangkan oleh Ajzen dan Fishbein (1998), perilaku yang ditampilkan oleh individu timbul karena adanya intensi atau niat untuk berperilaku. Sementara itu, munculnya niat berperilaku selain ditentukan oleh sikap dan norma subjektif, niat juga ditentukan oleh kontrol persepsi perilaku. Ketiga komponen ini berinteraksi dan menjadi indikator bagi niat yang pada gilirannya menentukan apakah perilaku tertentu akan dilakukan atau tidak.

Penelitian ini berfokus dalam memprediksi apakah sikap, norma subjektif, kontrol persepsi perilaku akan mempengaruhi perilaku pemilihan karir sebagai akuntan publik dengan minat sebagi variabel mediasi, karena minat yang kuat yang dimilikioleh mahasiswa dapat menimbulkan adanya perilaku aktual yang diwujudkan dengan berkarir pada profesi akuntan publik.

Pengembangan Hipotesis. Penelitian mengenai faktor-faktor yang memengaruhi mahasiswa akuntansi dalam memilih karier dilakukan oleh Rahayu, dkk (2003), mahasiswa akuntansi yang berminat menjadi akuntan publik hanya $14,17 \%$. Persepsi yang dimiliki seseorang akan sangat memengaruhi pemilihan karir mereka. Bila seseorang mempresepsikan suatu profesi secara negatif maka besar kemungkinan mereka akan menghindari atau tidak akan memilih profesi tersebut (Sugahara dan Boland, 2006).

Operasional variabel independen yang digunakan dalam penelitian ini adalah :

1. Sikap Terhadap Akuntan Publik. Yohanna Fajar Trikristiani (2014) dalam penelitiannya yang menunjukkan bahwa sikap mahasiswa terhadap akuntan publik berpengaruh positif terhadap minat mahasiswa akuntansi untuk menjadi akuntan publik.

$\mathrm{H}_{1}$ : Sikap pada profesi akuntan publik berpengaruh positif dan signifikan terhadap minat mahasiswa akuntansi untuk berkarir menjadi akuntan publik. 
2. Norma Subyetif. Penelitian Sulistiani (2012) menunjukkan faktor norma subjektif memiliki pengaruh yang signifikan terhadap minat mahasiswa akuntansi untuk menjadi akuntan publik yang juga didukung oleh penelitian Yohana Fajar (2014)

$\mathrm{H}_{2}$ : Norma Subjektif berpengaruh positif dan signifikan terhadap minat mahasiswa akuntansi untuk berkarir menjadi akuntan publik.

3. Kontrol Persepsi Prilaku. Yohanna Fajar Trikristiani (2014) dalam penelitiannya yang menunjukkan bahwa kontrol persepsi perilaku juga berpengaruh positif terhadap minat mahasiswa akuntansi untuk menjadi akuntan publik.

$\mathrm{H}_{3}$ : Kontrol Persepsi Prilaku berpengaruh positif dan signifikan terhadap minat mahasiswa akuntansi untuk berkarir menjadi akuntan publik.

4. Minat Berkarir Sebagai Akuntan Publik. Minat berkarir sebagai akuntan publik adalah variabel mediasi terhadap varibel sikap, norma subyektif dan kontrol persepsi prilaku terhadap prilaku berkarir sebagai akuntan publik yang menjadi variabel dependennya.

$\mathrm{H}_{4}$ : Minat mahasiswa akuntansi untuk berkarir menjadi akuntan publik berpengaruh positif dan signifikan terhadap pemilihan/prilaku berkarir sebagai akuntan publik

5. Berdasarkan model TPB, menujukkan variabel independen Kontrol Persepsi Prilaku dapat mempengaruhi Prilaku Berkarir Sebagai Akuntan Publik secara langsung tanpa dimediasi oleh variabel minat berkaris Sebagai Akuntan Publik.

$\mathrm{H}_{5}$ : Kontrol Persepsi Prilaku berpengaruh positif dan signifikan terhadap pemilihan/prilaku berkarir sebagai akuntan publik

6. Law (2010) meneliti bahwa faktor sikap terhadap perilaku (Law menyebutnya nilainilai intrinsik) memiliki hubungan yang signifikan dengan keputusan mahasiswa untuk berkarier pada akuntan publik. Felton et al., (1995) juga membuktikan bahwa mahasiswa yang berminat berkarier sebagai akuntan publik lebih memiliki sikap yang positif terhadap profesi tersebut. Berdasarkan penelitian yang dilakukan Sugahara dan Boland (2006) juga menunjukkan bahwa mahasiswa akuntansi memiliki sikap yang lebih positif terhadap profesi akuntan publik

$\mathrm{H}_{6}$ : Sikap pada profesi akuntan publik berpengaruh positif dan signifikan terhadap pemilihan/prilaku berkarir sebagai akuntan public melalui mediasi variabel Minar Berkarir Sebagai Akuntan Publik.

7. Juga dalam penelitian yang sama, Law (2010) mengatakan bahwa norma subjektif (Law menyebutnya parental influence) memiliki hubungan yang signifikan dengan keputusan mahasiswa untuk berkarier pada akuntan publik

$\mathrm{H}_{7}$ : Norma Subjektif berpengaruh positif dan signifikan terhadap pemilihan/prilaku berkarir sebagai akuntan publik.

8. Variabel Kontrol Persepsi Prilaku dalam model TPB selain dapat mempengaruhi Prilaku Berkarir Sebagai Akuntan Publik, juga variabel ini akan mempengaruhi Prilaku Berkarir Sebagai Akuntan Publik melalui varibel Minat Berkarir Sebagai Akuntan Publik sebagai variabel mediasi.

$\mathrm{H}_{8}$ : Kontrol Perilaku Persepsian berpengaruh positif dan signifikan terhadap pemilihan/prilaku berkarir sebagai akuntan publik.

\section{METODE}

Pengumpulan data menggunakan metode survei dengan menyebarkan kuesioner atau angket. Angket merupakan sehimpunan pertanyaan atau pernyataan mengenai suatu objek yang diajukan kepada dan untuk memperoleh tanggapan dari responden (Aritonang, 
1998:153). Populasi adalah mahasiswa perguruan tinggi/sekolah tinggi ekonomi swasta yang ada di Jakarta dengan kriteria mahasiswa akuntansi yang telah mendapatkan mata kuliah audit satu secara acak dengan menggunakan fasilitas google form Dari data yang masuk sampai batas waktu yang ditetapkan adalah sebagai berikut:

Tabel 1. Demografi Pengisian Kuesioner

\begin{tabular}{lc}
\multicolumn{1}{c}{ Perguruan Tinggi } & Jumlah \\
\hline Universitas Tarumanagara & 32 Responden \\
Univeristas Trisakti & 24 Responden \\
Universitas Atma Jakarta & 27 Responden \\
Universitas Binus & 23 Responden \\
Total & 106 Responden
\end{tabular}

Sumber: data kuesioner yang terkumpul

\section{HASIL DAN PEMBAHASAN}

Pengujian data penelitian. Pengujian dengan tingkat keyakinan $95 \%$ dengan menggunakan Stata. Hasil dari pengolah disajikan sebagai berikut:

Tabel 2. Hasil Pengujian Koefisien dan Signikansi

Hubungan Langsung

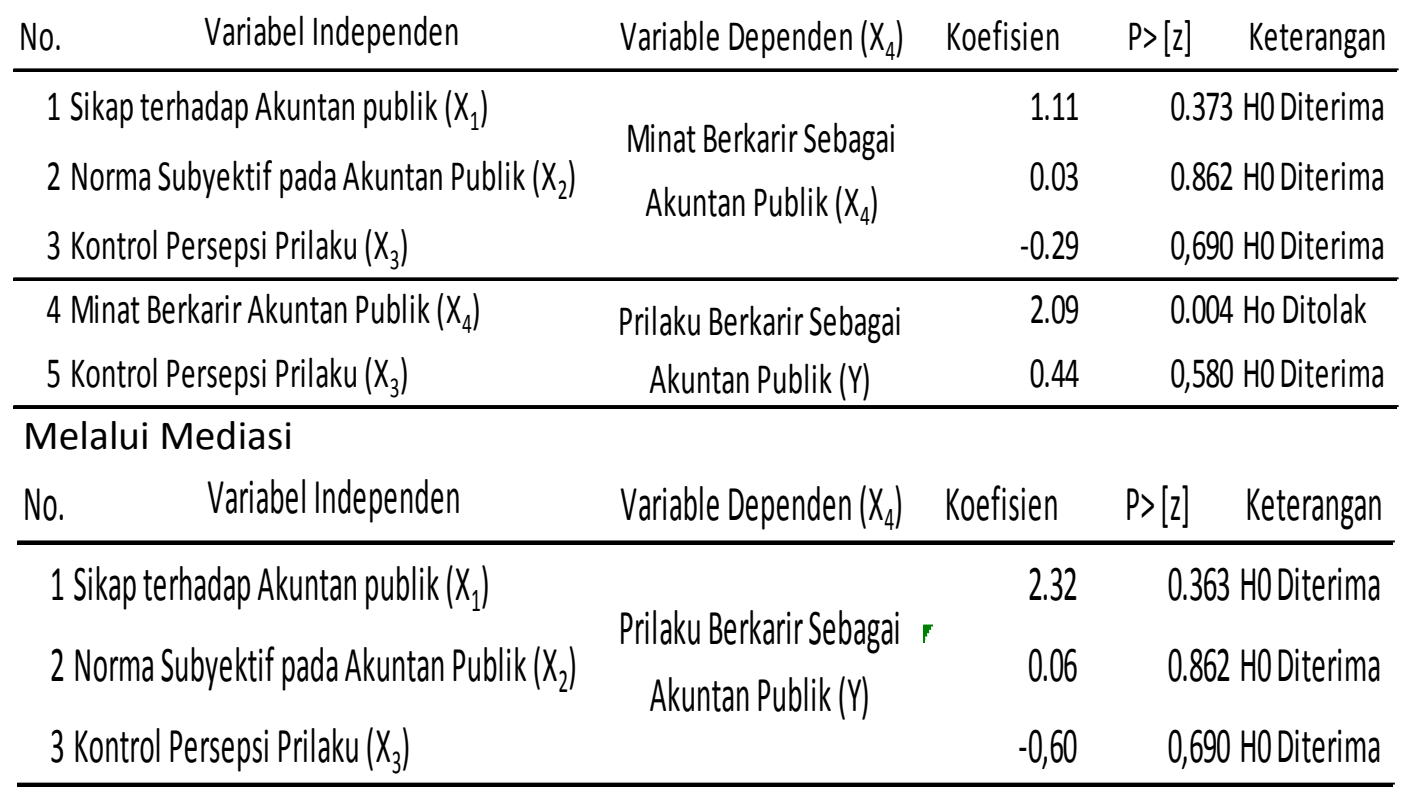

Sumber: Hasil Olah Stata 


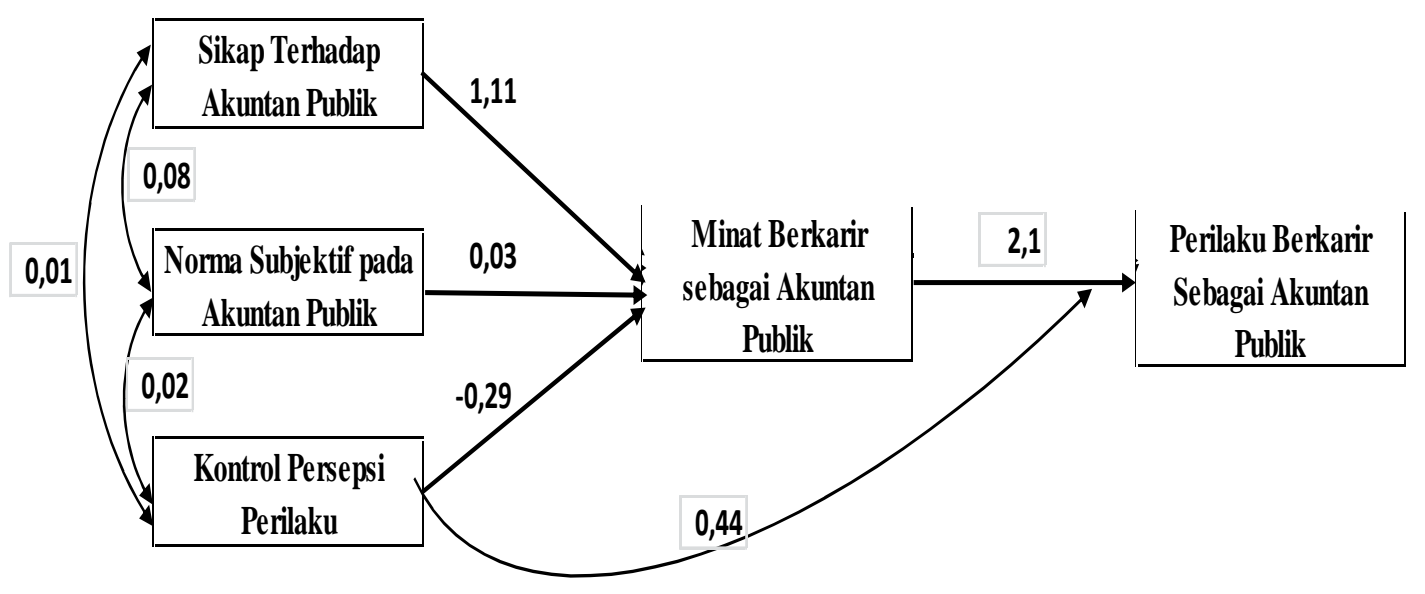

Gambar 2. Koefisien Antara Variabel

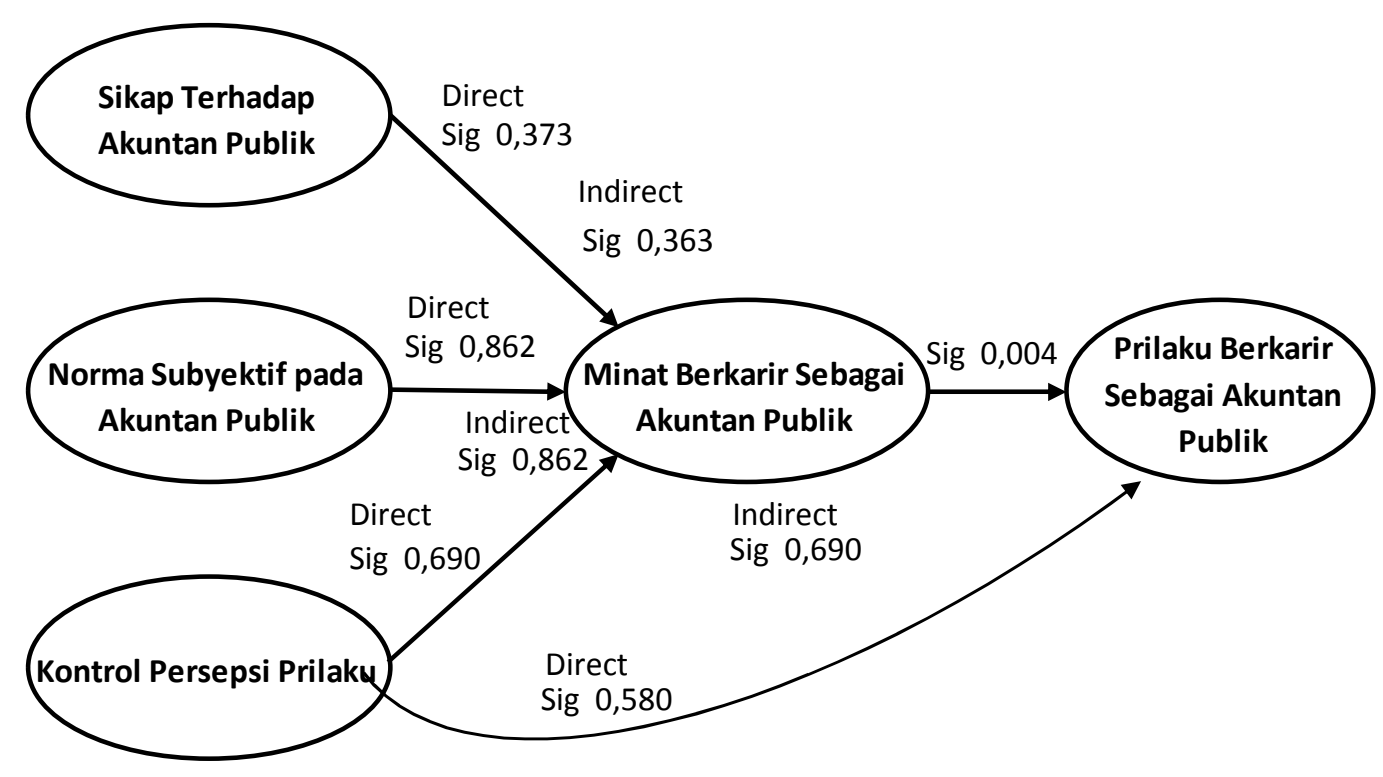

Gambar 3. Pengaruh Variabel Independen terhadap Variabel Dependen

Hubungan variabel independen secara langsung, Sikap terhadap Akuntan Publik mmpunyai hubungan yang relatif kuat $(1,11)$ dibanding dengan variabel Norma Subyektif $(0,03)$ dan Kontrol Persepsi Prilaku $(-0,29)$ terhadap variabel Minat Berkarir Sebagai Akuntan Publik menunjukkan hubungan yang lemah, bahkan ada yang mempunyai hubungan negatif. Begitu pula bila dilihat dari signifkansi hubungan ketiga variabel independen terhadap variabel Minat Berkarir sebagai Akuntan Publik tidak ada yang signifikansi (lebih kecil dari 0,05). Begitu pula kontrol persepsi prilaku terhadap prilaku berkarir sebagai akuntan publik menunjukkan hubungan yang lemah dan tidak signifikan. Namun minat berkarir sebagai akuntan publik menunjukkan hubungan yang cukup kuat 
$(2,09)$ dan menunjukkan adanya sigfikansi hubungan minat dengan prilaku berkarir sebagai akuntansi publik (0.004).

Ketika variabel Sikap Terhadap Akuntan Publik, Norma Subyektif, dan Kontrol Persepsi Prilaku dimediasi dengan variabel Minat Berkarir Sebagai Akuntan Publik, juga menunjukkan hubungan yang lemah, hanya variabel Sikap Terhadap Akuntan Publik yang cukup kuat $(2,32)$, dan semua variabel independen menunjukkan tidak ada hubungan signifkan terhadap Prilaku Karir Sebagai Akuntan Publik.

Mahasiswa umumnya mempunyai niat berprfesi sebagai akuntan publik. Ini didukung juga dengan Sikap Terhadap Akuntan Publik. Namun secara di alam bawa sadar, merka umumnya tidak berniat menjadi akuntan publik bahkan berprilaku sebagai akuntan publik. Ini terlihat jelas dari sikap norma yang berasal dari alam bawa sadar mereka. Bahkan dilihat dari perspesi prilaku menunjukkan angka yang negatif, yang artinya tidak sekali berminat. Dalam kenyataannya, mahasiswa yang belum mempunyai pengalaman bekerja sebagai akuntan publik menunjukkan keinginan mereka menjadi akuntan publik pada saat masa kuliah, dan ini terlihat pada nilai sikap yang cukup besar terhadap niat dan berprilaku sebagai akuntan publik. Hal ini terjadi karena dalam pikiran mahasiswa bahwa kalau belajar akuntansi harus bekerja sebagai akuntan publik walaupun tujuan akhir profesi yang akan digeluti adalah bukan sebagai akuntan publik. Hal ini dapat disebabkan karena selama mendapat pendidikkan akuntansi, selalu ditekanan bahwa pekerjaan akuntansi adalah sebagai akuntan, atau mendapatkan peran model dari dosen yang berprofesi sebagai akuntan publik. Jadi dapat disimpulkanm bahwa bagi mahasiswamahasiswi yang belajar diperguruan tinggi swasta di Jakarta, pilihan kerja sebagai akuntan publik hanya sebagai "batu loncatan" atau "kerja praktik" sebelum menuju profesi yang diingini.

\section{PENUTUP}

Simpulan. Berdasarkan hasil olah di atas, dapat diambil kesimpulan bahwa dari data yang diperoleh bahwa mahasiswa akuntansi dari perguruan tinggi swasta yang berpartisipasi dalam peneletian ini dapat disimpulkan bahwa menjadi akuntan publik bukan menjadi tujuan karir mereka namun mereka mempunyai minat bekerja sebagai akuntan publik dalam jangka pendek. Ini terlihat adanya hubungan minat dan karir yang cukup kuat dan mempunyai hubungan yang signifikan, tetapi kerja sebagai akuntan tidak dicerminkan pada sikap, norma dan prilaku mereka. Dengan kata lain, dapat disimpulkan bahwa mareka berkeja sebagai akuntan publik hanya pemberhentian sementara untuk mendapatkan pengalaman, setelah dirasakan cukup menimbah pengalaman, maka mereka akan mencari pekerjaan atau profesi lain.

Keterbatasan dan Implikasi. Penelitian ini jauh dari sempurna dan dilakukan dengan segala keterbatasan baik dari segi waktu, cakupan subyek dan hanya dilakukan di perguruan tinggi di Jakarta.

Implikasi dari penelitian ini menunjulkkan minat mahasiswa meniti karir sebagai akuntan publik sangat minim, atau berdasarkan penelitian ini dengan data yang data menunjukkan tidak ada yang berkeinginan menjadi akuntan publik karena lemahnya persepsi yang pada mahasiswa dari perguruan tinggi swasta. Hal ini bisa disebabkan karena para senior mereka juga kerja di kantor akuntan publik sebagai batu loncatan, kerja di kantor akuntan hanya untuk mencari pengalaman kerja bukan sebagai karir, gaji yang relatif kecil dibanding dengan akuntan manajemen, waktu kerja yang tidak teratur, atau 
melihat bahwa profesi akuntan lainnya atau diindustri non kantor akuntan mempunyai penghasilan yang lebih baik

\section{DAFTAR RUJUKAN}

Andersen. (2012) “Analisis Persepsi Mahasiswa Akuntansi Dalam Memilih Profesi Sebagai Akuntan (Studi Empiris Pada Mahasiswa Akuntansi Undip, Unika, Unnes, Unissula, Udinus, Unisbank, Stie Totalwin Dan Mahasiswa Ppa Undip)". Jurnal Universitas Diponegoro: Semarang.

Ajzen, I. \& Fishbein, M., (1977) "Attitude-behavior relations: A theoretical analysis and review of empirical research". Psychological bulletin, 84(5), 888-918.

Ajzen, Icek, (1991) The theory of Planned Behavior, Organizational, Behavior, and Human Decision Processes 50, 179-211.

Ajzen, I., \& Fishbein, M. (1998) Understanding Attitude and Predicting Social Behavior. Englewood Cliff. New York: Prectice Hall.

Aritonong,R Lerbin. (1998) Penelitian Pemasaran. Jakarta. UPT universitas Tarumanagara.

Azwar, Saifuddin, (2003) Sikap Manusia Teori dan Pengukurannya, Edisi 2 Pustaka Pelajar, Yogyakarta.

Bagley, Penelope, L., Dalton, derek., Ortogren, Marc. (2012) "The factors that Affect Accountants' Decision to Seek Career with Big 4 versus Non-Big 4 Accounting Firms", Accounting Horizon, 26 (2), 238-264.

Baron, R.A. \& Byrne, D., (1984) Social psychology understanding human interaction, Boston: Allyn \& Bacon.

Felton, Sandra., Buhr, Nola dan Northey, Margot. (1994) "Factors influencing the business students' choice of a career in Chartered Accountancy". Issues in Accounting Education. (9.1), 131-141

Gary, Iain, Manson, Stuart,and Crawford, Louise, 2015, The Audit Process:Priciples, Practice and Case, Sixth Edition, Singapore. Cengage Learning.

Hasbullah, Norazhan., Mahajar, Abdul Jumaat., Salleh, MadIthin, (2014) "Extending the Theory of Planned Behavior; Evidence of the Argument of its Suffuciency", International Journal of Humaninities and Social Science, 4 (14), December.

Hsu, M. H. And Chiu, C. M. (2002) "Predicting Electronic Service Continuance with a Decomposed Theory of Planned Behavior, "Behavior \& Information Technology

Jogiyanto, (2007) Sistem Informasi Keperilakuan. Edisi Revisi. Yogyakarta: Andi Offset

Law, Philip K. (2010) "A theory of reasoned action model of accounting students' career choice in public accounting practices in the post-Enron". Journal of Applied Accounting Research. 11(1), 58-73

Rahayu, Sri. (2003) "Persepsi Mahasiswa Mengenai Faktor - Faktor yang Mempengaruhi Pemilihan Karir". Simposium Nasional Akuntansi VI.Surabaya, 16-17 Oktober, 821838.

Sugahara, Satoshi dan Gregory Boland. (2006) "Perceptions of the Certified Public Accountants by Accounting and Non-accounting Tertiary Students in Japan". Asian Review of Accounting, 14 (1/2), 149-167.

Sulistiani. (2012) Faktor-faktor yang memengaruhi Niat mahasiswa akuntansi untuk Berkarier sebagai akuntan publik: Aplikasi theory of planned behavior (studi empiris pada mahasiswa universitas diponegoro). Jurnal Universitas Diponegoro: Semarang. 
Trikristiani. (2014) "Pengujian Theory of Planned Behavior dan Pengaruh Pemahaman terhadap Undang-Undang Nomor 5 Tahun 2011 tentang Akuntan Publik terhadap Intensi Mahasiswa Akuntansi untuk Berkarier Menjadi Akuntan Publik". Skripsi. Program Studi Akuntansi Universitas Negeri Yogyakarta.

Zaid. (2015) Pengaruh Gender, Penghargaan Finansial, Dan Pertimbangan Pasar Kerja Terhadap Minat Mahasiswa Akuntansi Untuk Berkarier Menjadi Akuntan Publik (Studi Kasus Pada Mahasiswa Akuntansi Universitas Negeri Yogyakarta). Skripsi Universitas Negeri Yogyakarta: Yogyakarta.

www.worldbank.org

forlap.dikti.go.id 